\title{
Effect of the Application of Poultry Manure and Wood Ash on Maize (Zea mays L.) Performance
}

\author{
G.O. Dayo-Olagbende ${ }^{1, a^{*}}$, O.J. Ayodele ${ }^{2, b}$ and G.I. Ogunwale ${ }^{1}$ \\ ${ }^{1}$ Crop, Soil and Pest Management, School of Agriculture and Agricultural Technology, Federal \\ University of Technology, Akure, Nigeria. \\ ${ }^{2}$ Ekiti State University, Crop, Soil and Environmental Sciences, Faculty of Agricultural Sciences \\ aphemmieisrafel@gmail.com, bolufemiayodele@yahoo.com
}

Keywords: Plant height, Poultry manure, Maize seeds, Wood ash.

\begin{abstract}
A field experiment was carried out to evaluate the effect of the application of poultry manure and wood ash on the growth and grain yield of maize (Zea mays L.). The poultry manure was applied two weeks prior to planting to allow for proper decomposition. Wood ash was applied a day before planting. There were three treatments in all including the control and the treatments were arranged in a randomized complete block design (RCBD) with three replicates. Plant height and leaf area were taken at three weeks after planting to nine weeks after planting with an interval of two weeks. The grain yield was taken at eleven weeks after planting and was dried, weighed and recorded. The results showed that poultry manure significantly increased plant height $(192.0 \mathrm{~cm})$ and grain yield $(4.83 \mathrm{t} / \mathrm{ha})$ but has no significant effect on the number of leaves and leaf area with $12 \mathrm{~cm}$ and $3403.6 \mathrm{~cm}^{2}$ respectively. The values of plant height and leaf area of the control were relatively high compared with other treatments. This can be attributed to the availability of Nitrogen in the soil. The wood ash was found to give the lowest values for nitrogen as well as vegetative growth of maize, this could be attributed to the fact that nitrogen tends to volatilize when in contact with alkaline mediums and consequently affect vegetative growth of maize.
\end{abstract}

\section{Introduction}

Production of biomass by agriculture and forestry is one of the main functions the soil serves that has relevance to human life. This is possible by its ability to supply the nutrients needed to support plant growth and development [6]. Shifting cultivation (bush fallow or land rotation) practices had been adopted to ensure natural soil nutrient replenishment but pressure on arable land from the development of socio-economic infrastructure; urbanization and high population growth rate are responsible for shortening the fallow lengths, making the practice ineffective. Continuous cultivation, which the farmers are compelled to adopt has already been indicted for soil degradation characterized by rapid depletion of soil nutrients and organic matter with dire consequences on the food production [2, 12]. This nutrient depletion threatens the sustainability of crop production system such that considerations have always been given to the issue of nutrient replenishment as part of general improvement on soil fertility. The low fertilizer use rate and soils with inherent poor fertility put a ceiling on the yield of maize-a high nutrient demanding crop $[3,6]$. This 'nutrient mining' that characterizes such crop production systems has stimulated interests in the potentials of organic materials, especially the huge quantities of agricultural and forest products processing wastes generated and which pose disposal challenges. The wastes (dung) from poultry production under intensive management systems and burning materials which generates smoke which fouls the air while harmful organic compounds from the decay processes are leached into ground water sources [6].

Poultry manure has been accepted as a source of nutrients for crop production and its application increases crop yield through a general improvement in growth parameters [5]. Wood ash lacks nitrogen $(\mathrm{N})$, but contains oxides and hydroxides of basic cations such that its soil application in ancient agriculture raises soil $\mathrm{pH}$, a process application which increases the availability of nutrient such as phosphorus $(\mathrm{P})[13]$. 
The different compositions of poultry manure and wood ash mean that their support of plant growth will vary. The objective of this investigation is therefore, to assess the response of maize (Zea mays L.) to application of poultry manure and wood ash as a sole application. This study sets out to determine the effect of poultry manure and wood ash on the growth and yield of maize (Zea mays L.)

\section{Materials and Methods}

The experiment was carried out at the Teaching and Research Farm of the Faculty of Agricultural Sciences, University of Ado Ekiti (Now Ekiti state University) located at $7^{0} 37^{1} \mathrm{~N}$ and longitude $5^{0} 15^{1} \mathrm{E}$ in south western, Nigeria. The area experiences a tropical climate with distinct wet and dry seasons. Mean annual total rainfall is about $1337 \mathrm{~mm}$ while temperature is almost uniform throughout the year with very little deviation from annual mean having an average minimum temperature of $21{ }^{\circ} \mathrm{C}$ and average maximum temperature of $27{ }^{\circ} \mathrm{C}$. The annual total sunshine hour is about 2000 hours while mean annual radiation of about $130 \mathrm{Kcal} \mathrm{cm}^{3}$ per year. The vegetation is forest mixed with various types of bush re-growths, grasses and creepers.

A land area measuring $40 \times 25 \mathrm{~m}$ was ploughed, harrowed and surface soil samples $(0-15 \mathrm{~cm})$ collected randomly and bulked together from which a composite sample was taken. The samples was air-dried and passed through $2 \mathrm{~mm}$ sieve and analyzed for major physical and chemical properties using methods outlined by International Institute of Tropical Agriculture IITA [9]. Soil pH was determined in 1:2 soil solutions using distilled water and read on a $\mathrm{pH}$ meter, particle size distribution by hydro meter method, organic method and exchangeable cations extracted with neutral normal ammonium acetate, exchangeable Potassium $(\mathrm{K})$ and Sodium $(\mathrm{Na})$ were read with flame photometer while Calcium $(\mathrm{Ca})$ and Magnesium $(\mathrm{Mg})$ were determined by Atomic Absorption Spectrophotometer.

\section{Soil Amendments}

Two materials were used as soil amendments: poultry manure and wood ash. Poultry manure was collected from the livestock unit of the Teaching and Research Farm, University of Ado Ekiti. Sawdust was collected from a sawmill at Ado Ekiti and was burnt to produce wood ash. The materials were evaluated singly as follows:

$$
\begin{aligned}
& \mathrm{T}_{1}=\text { Control } \\
& \mathrm{T}_{2}=\text { Poultry manure } \\
& \mathrm{T}_{3}=\text { Wood ash }
\end{aligned}
$$

The poultry manure was applied as a sole treatment. Wood ash was also applied as a sole treatment while $\mathrm{T}_{1}$ (control) treatment do not have any poultry manure or wood ash treatment.

\section{Planting Materials}

Yellow maize variety TZSRE-Y was sourced from the seed processing unit of the Ekiti State Agricultural Development Programme. The seeds were treated with Apron Plus 50 DS before planting.

\section{Establishment}

The harrowed land was marked out into $3 \times 1.5 \mathrm{~m}$ plots separated by $1 \mathrm{~m}$ wide paths. Treatments were assigned to the plots in a randomized complete block design (RCBD) with three replications. Poultry manure was applied and mixed with the surface layer of each plot two weeks before planting. Wood ash was applied a day before planting to avoid it being washed away. The seeds were sown 2-3 seeds per hole at $75 \times 25 \mathrm{~cm}$ spacing and seedlings thinned to one stand per whole 10 days after planting. 


\section{Data Collection}

Three maize stands were tagged and used for collecting data to measure the growth trend in each treatment. The data collection started three weeks after planting and at an interval of two weeks of the following growth parameters: Plant height, leaf area, number of leaves.

\section{Harvesting and Processing}

Harvesting of the maize cob was carried out 11 weeks after planting. The harvested cobs were shelled and sundried for two weeks before final weighing.

\section{Statistical Analysis}

Statistical analyses of all data collected were carried out using Analysis of Variance (ANOVA) and the means were compared using the Least Significant Difference (LSD).

\section{Results and Discussion}

The physical and chemical properties of the soil in the experiment site are shown in Table 1. The soil was strongly acid organic content. Total $\mathrm{N}$ at $0.13 \%$ was moderately low [1] but similar to the mean value soils in Southwestern Nigeria [7].

Exchangeable $\mathrm{K}$ was high being more than $0.16-0.20 \mathrm{Cmol}-\mathrm{kg}^{-1}$ critical levels established for maize in soils of Nigeria while available $\mathrm{P}$ was low [14]. Thus, the site can be regarded as moderately fertile.

The nutrient content of the poultry manure and wood ash used for the study are shown in Table 2. The fresh poultry manure obtained from the layers section contains $1.25 \% \mathrm{~N}, 1.38 \% \mathrm{P}$, $0.89 \% \mathrm{~K}, 1.92 \% \mathrm{Ca}, 0.29 \% \mathrm{Mg}$ and $0.32 \% \mathrm{~S}$. The wood ash contains $\mathrm{O} \% \mathrm{~N}$ and $\mathrm{S}$. It is a product of burnt wood. During burning $\mathrm{N}$ and $\mathrm{S}$ are completely oxidized and lost through volatilization while more $\mathrm{K}$ and $\mathrm{Ca}$ in the woodash are released into the soil thereby increasing the availability for plants and to control soil acidity.

Table 1. Physical and chemical properties of the soil at the teaching and Research Farm, Ekiti State University, Ado Ekiti

\begin{tabular}{lc}
\hline Parameters & Values \\
\hline $\mathrm{pH}($ Water $)$ & 5.4 \\
Sand, \% & 68.8 \\
Clay, \% & 26.5 \\
Silt, \% & 5.7 \\
Textural class & sandy loam \\
Organic matter, \% & 2.48 \\
Total $\mathrm{N}, \%$ & 0.13 \\
$\mathrm{Mg}^{2+}, \mathrm{Cmol.} \mathrm{Kg}^{-1}$ & 3.4 \\
$\mathrm{Ca}^{2+}, \mathrm{Cmol} . \mathrm{Kg}^{-1}$ & 6.50 \\
$\mathrm{Na}, \mathrm{Cmol.} \mathrm{Kg}^{-1}$ & 0.43 \\
$\mathrm{~K}^{+}, \mathrm{Cmol} . \mathrm{Kg}^{-1}$ & 0.17 \\
Available P & 3.02 \\
\hline
\end{tabular}

Table 2. Average nutrient values of the organic amendments and woodash(\%)

\begin{tabular}{lcccccc}
\hline Nutrient sources & $\mathrm{N}$ & $\mathrm{P}$ & $\mathrm{K}$ & $\mathrm{Ca}$ & $\mathrm{Mg}$ & $\mathrm{S}$ \\
\hline & & & & & & \\
Poultry manure & 1.25 & 1.38 & 0.89 & 1.92 & 0.27 & 0.32 \\
Wood ash & 0.00 & 0.09 & 0.29 & 0.89 & 0.04 & 0.00 \\
\hline
\end{tabular}


Table 3 shows that at 3 weeks after planting (WAP), the poultry manure treatment had the tallest plants while application of wood ash produced the shortest plants. There are no significant differences between the poultry manure treatment and control treatment. At 5 WAP, Poultry manure treatment and control treatment was not significant. At 7 and 9 WAP, the tallest plants were from the application of poultry manure. There were significant differences among the treatments. Though, at 9 WAP, the plant heights were almost the same because at this stage, the plants had produced ears. This trend in growth shows that poultry manure increased plant height up to 7 WAP which agrees with observations made by Boetang et al. [5] and O. Dayo-olagbende [6].

Table 3. Effects of soil amendments on heights (cm) of maize (Zea mays L.)

\begin{tabular}{lcccc}
\hline Amendments & 3 & 5 & 7 & 9 \\
\hline Control & $30.4 \mathrm{ab}$ & $63.2 \mathrm{ab}$ & $139.3 \mathrm{~b}$ & $191.8 \mathrm{ab}$ \\
Poultry manure & $33.4 \mathrm{a}$ & $66.8 \mathrm{a}$ & $161.1 \mathrm{a}$ & $192.0 \mathrm{a}$ \\
Wood ash & $27.6 \mathrm{~b}$ & $54.5 \mathrm{~b}$ & $125.7 \mathrm{c}$ & $186.6 \mathrm{~b}$ \\
\hline
\end{tabular}

Means followed by the same letter are not significantly $(\mathrm{P}<0.05)$ different according to LSD.

There were no significant differences between the treatments as regards number of leaves at 3 and 5 WAP. The poultry manure treatment gave the largest leaf area at $3 \mathrm{WAP}$ while the wood ash treatment had the least. At $5 \mathrm{WAP}$ all the treatments have similar values while at $7 \mathrm{WAP}$ only wood ash treatment had the lowest. This is due to the fact that $\mathrm{N}$ is lost as $\mathrm{NH}_{3}$ gas when it comes in contact with high $\mathrm{pH}$ materials like wood ash [8].

Tables 4 and 5 show the effects of soil amendments on the number of leaves and leaf area per plant respectively.

The grain yield of maize as affected by soil amendments is presented in Table 6 . The poultry manure amendment gave the highest maize yield while the control was the least. The poultry manure recorded the highest maize yield because it supplied nutrients which were probably not available in sufficient quantities in the soil and so confirms work done by Bhogal et al. [4], Saviozzi et al. [11]. Wood ash is known to be low in $\mathrm{N}$ and which accounts for its poor yield when compared with poultry manure [10].

Table 4. Effect of amendments on number of leafs

\begin{tabular}{cccc}
\hline Amendments & 3 & 5 & 7 \\
\hline Control & $8.00 \mathrm{a}$ & $12.00 \mathrm{a}$ & $14.00 \mathrm{a}$ \\
Poultry manure & $8.00 \mathrm{a}$ & $12.00 \mathrm{a}$ & $14.00 \mathrm{a}$ \\
Wood ash & $8.00 \mathrm{a}$ & $12.00 \mathrm{a}$ & $14.00 \mathrm{a}$ \\
\hline
\end{tabular}

Means followed by the same letter are not significantly $(\mathrm{p}<0.05)$ different according to LSD.

Table 5. Effect of amendments on leaf area $\left(\mathrm{cm}^{2}\right) \cdot$ plant $^{-1}$

\begin{tabular}{lrcc}
\hline Amendments & 3 & 5 & 7 \\
\hline Control & $436.9 \mathrm{~b}$ & $1127.8 \mathrm{a}$ & $3422.8 \mathrm{a}$ \\
Poultry manure & $553.2 \mathrm{a}$ & $1165.9 \mathrm{a}$ & $3403.6 \mathrm{a}$ \\
Wood ash & $388.6 \mathrm{a}$ & $118.9 \mathrm{a}$ & $3055.4 \mathrm{~b}$ \\
\hline
\end{tabular}

Means followed by the same letter are not significantly $(\mathrm{p}<0.05)$ different according to LSD.

Table 6. Effects of soil amendments on maize grain yield. $\left(\mathrm{mt}^{-\mathrm{ha}^{-1}}\right)$.

\begin{tabular}{lc}
\hline Amendments & Grain yield \\
\hline Control & $2.27 \mathrm{c}$ \\
Poultry manure & $4.83 \mathrm{a}$ \\
Wood ash & $2.94 \mathrm{~b}$ \\
\hline
\end{tabular}

Means followed by the same letter are not significantly $(\mathrm{p}<0.05)$ different according to LSD. 


\section{Conclusion}

The study was carried out to evaluate the effect of soil application of some environmentally hazardous materials namely poultry manure, wood ash on the growth and yield of maize (Zea mays L.). The amendments were applied and worked into the top soil prior to planting. Three maize seeds were planted which was later thinned to one stand after two weeks of planting. The treatments were replicated three times. Measurements of growth parameters are plant height, leaf area and number of leaves was recorded from 3-9 WAP while cobs were harvested, shelled and weighed.

The results showed that the application of poultry manure alone recorded the highest grain yield followed by wood ash application. In a situation where scarcity and high cost limits the availability of inorganic fertilizer, poultry manure will be a possible alternative. It can boost maize yield when cost of inorganic fertilizer is high. A soil rich in $\mathrm{N}$ and deficient in other nutrients can be amended by a mixture of poultry manure and wood ash. However, care should be taken to make sure that these organic amendments do not contain unknown or toxic additives that can depress the plant growth. This study did not evaluate the costs involved. Hence, further studies can be carried out to evaluate the cost implication.

\section{Conflict of Interest}

The authors declare that there is no conflict of interest.

\section{References}

[1] Anon, 2006. Nigeria Fertilizer strategy Report Presented at Africa Fertilizer summit held at International count Center, Abuja, $9^{\text {th }}-13^{\text {th }}$ June, 2006, 47 pp.

[2] A.E. Adekogba, L.A. Akinbile, Impact of Agricultural development on Environmental Sustainability: a threat to food security in poverty alleviation, Journal of Poverty Alleviation and Food Security in Nigeria. (1999) 10-13.

[3] O.J. Ayodele, O.A. Aruleba, The fertilizer solution to problems of soil impoverishment in Nigeria, Journal of Environmental Conservation and Research. 1 (2007) 71-78.

[4] A. Bhogal, S.D Young, R. Sylvester, Straw incorporation and immobilization of spring applied nitrogen, Soil Use and Management. 13 (1997) 111-113.

[5] S. Boetang, J. Zickkerman, S.M. Kornarhrens, Poultry manure effect on growth and yield of maize, West Africa Journal of Applied Ecology. 9 (2006) 1-11.

[6] O. Dayo-Olagbende, The effect of the Application of poultry manure, sawdust, wood ash, inorganic fertilizer and their mixtures on maize (Zea mays L.). Performance. B. Agric project work, 2010, Department of Crop, Soil and Environmental Sciences, Faculty of Agricultural Sciences, University of Ado Ekiti, Nigeria (June, 2010), pp. 41.

[7] FMANR, Literature review on soil fertility investigations in Nigeria (in Five Volumes). Federal Ministry of Agriculture and Natural Resources, Lagos, 1990, pp. 32-45.

[8] D.H. Fredrick, Using fireplace ash in your garden. The master gardeners, 2004, pp. 1-3.

[9] International Institute of Tropical Agriculture, Selected methods in Soil and Plant Analysis. Manual Series No 1. International Institute of Tropical Agriculture (IITA), Ibadan, Nigeria, 1979, 70 pp.

[10] A. Olayinka, Nitrogen and phosphorus uptake by maize (Zea mays L.) as affected by depth of animal manure incorporation, Samaru Journal of Agriculture Research. 13 (1994) 59-66.

[11] A. Saviozzi et al., Laboratory studies on the application of wheat straws and pig slurry to soil and its resulting environmental implication to agriculture, Ecosystem and Environment. 61 (1997) 38-43. 
[12] J.J. Sim, S.D. Cunninggham, M.E. Summer, Assessing soil quality for environmental purposes-roles and challenges for soil scientists, Journal of Environmental Quality. 26 (1997) $20-25$.

[13] S. Karki, Community involvement in and management of forest fires in South East Asia, Project FireFight South East Asia, 2002.

[14] O.J. Ayodele, A.A. Agboola, Evaluation of phosphorus in Savannah soils of Western Nigeria under bush fallow systems, The Journal of Agricultural Science. 101(2) (1983) 283-289. 